\title{
SUSTAINABILITY COST ACCOUNTING - PART 2: A CASE STUDY IN THE SOUTH AFRICAN PROCESS INDUSTRY
}

\author{
A.C. Brent ${ }^{1,2}$, R.P.G. van Erck ${ }^{1}$ and C. Labuschagne ${ }^{1}$ \\ ${ }^{1}$ Chair of Life Cycle Engineering \\ Department of Engineering and Technology Management \\ University of Pretoria, South Africa \\ alan.brent@up.ac.za \\ ${ }^{2}$ Resource Based Sustainable Development \\ Natural Resources and the Environment, CSIR, South Africa
}

\begin{abstract}
A Sustainability Cost Accounting (SCA) procedure has been introduced that expresses the impacts on sustainable development associated with a developed technology, by means of a common financial denominator. This paper uses a case study to demonstrate and assess the SCA procedure, which considers the construction and operation of a hypothetical Gas-to-Liquid (GTL) fuelmanufacturing facility at a specific location in South Africa. The SCA indicators show that the negative environmental impacts associated with the GTL technology outweigh the internal economic benefits for the company. However, a net positive social benefit is associated with the technology, which decision-makers should consider with respect of the overall sustainability of the technology. Certain limitations of the SCA procedure are highlighted, and recommendations are made to develop such a methodology further.
\end{abstract}

\section{OPSOMMING}

'n Volhoubaarheid Koste-Rekeningkunde prosedure (VKR) word voorgestel waarvolgens die impakte van 'n ontwikkelde tegnologie op volhoubaarheid in 'n gemeenskaplike finansiële waarde aangegee kan word. 'n Gevallestudie word hier gebruik om die VKR-prosedure te demonstreer. Die gevallestudie beskryf die konstruksie en bedryf van 'n hipotetiese Gas-tot-Vloeistof brandstofvervaardigingsfasiliteit (GTV) in 'n spesifieke area van Suid-Afrika. Die VKR-indikators dui aan dat die negatiewe omgewingsimpakte van die GTV tegnologie tot ' $n$ geringe mate groter is as die interne ekonomiese voordele vir die maatskappy. Die tegnologie het wel oorwegende positiewe sosiale voordele wat besluitnemers in ag moet neem wanneer die globale volhoubaarheid van die tegnologie ge-assesseer word. Sekere beperkinge van die VKR-prosedure word uitgelig en voorstelle word gemaak om dié tipe metodologie verder te ontwikkel. 


\section{INTRODUCTION}

In Part 1 of this paper, a monetary methodology was proposed to assess the sustainability of developed technologies. Here, Part 2 deals with a hypothetical (technology) case study in which the process industry in South Africa applies the proposed Sustainability Cost Accounting (SCA) procedure. The case study increases understanding of the possible practical obstacles of the methodology. Furthermore, it reveals how positive and negative impacts of a specific technology in the process industry on sustainability relate to each other. The case study indicates what the major impacts are of a specific technology in a specific location, and how these impacts are expected to change if certain system conditions change.

Three of the key premises to apply the SCA procedure in the case study are:

- The assessment merely focuses on the environmental, social, and economic sustainability of a specific operational initiative (or technology); therefore, all Corporate Social Responsible (CSR) projects that are not associated with the specific technology are excluded.

- The assessment is exclusively based on the indicators that have been proposed for the SCA procedure (in Part 1). Therefore not all of the criteria of a comprehensive sustainable development framework receive full consideration. The implications of this limitation are addressed.

- An assessed technology is inextricably bound to its location, in that the associated regional or local impacts (of the technology) are site-specific.

All the cost figures are reported in the South African Rand currency (at 2002 price levels) which, at the beginning of 2006, traded at a level of about R6 to 1 US\$, or R8 to $1 €$.

\section{SCOPE OF THE HYPOTHETICAL CASE STUDY}

\subsection{Location of the case study}

The case study aims to assess the overall sustainability of the known Gas-to-Liquid (GTL) technology, which converts natural gas to liquid fuels [1]. The assessment is based on a full-scale production plant in the town of Secunda in central South Africa. Secunda exists solely due to the construction of a Coal-to-Liquid (CTL) manufacturing plant. The operation of the (hypothetical) plant is assumed to be similar to the current facility in Secunda. However, no process-specific data are used from the existing plant. Rather, published data are used, e.g. reported life cycle inventories [2].

The choice of the setting is important for the SCA procedure, as site-specific data such as real estate prices, land prices, and population density, affect the outcome of the procedure. The primary advantage of using the Secunda site for the case study is its isolated setting, which makes it simpler to recognise and attribute different 
impacts on the operational activity, especially with respect to environmental and social factors. Impacts are often difficult to attribute to one operational activity alone if a plant is located in an established industrial area. In the case of Secunda, the region consisted of agricultural land - primarily maize and livestock - before the coal-based plant was constructed. Even now, no major industries have emerged in the immediate vicinity of the main petrochemical facility. Furthermore, a Strategic Environmental Assessment (SEA) of Secunda is available in the public domain, which provides more detailed information on environmental and social impacts around this specific site [3]. In particular, patterns of pollutants and information about water use and land use are valuable.

\subsection{Boundaries of the case study}

All impacts on sustainability resulting from a deployed technology can be attributed to two distinct life cycles: the life cycle of the technology itself, and the life cycle of the product (or service) that arises from the implemented technology [4]. Figure 1 illustrates the integration of the two life cycles for a technology in the process industry. In the Figure, the process life cycle is represented by two axes: one axis focuses on the physical structure of the plant (or technology), and the other represents the product life cycle.

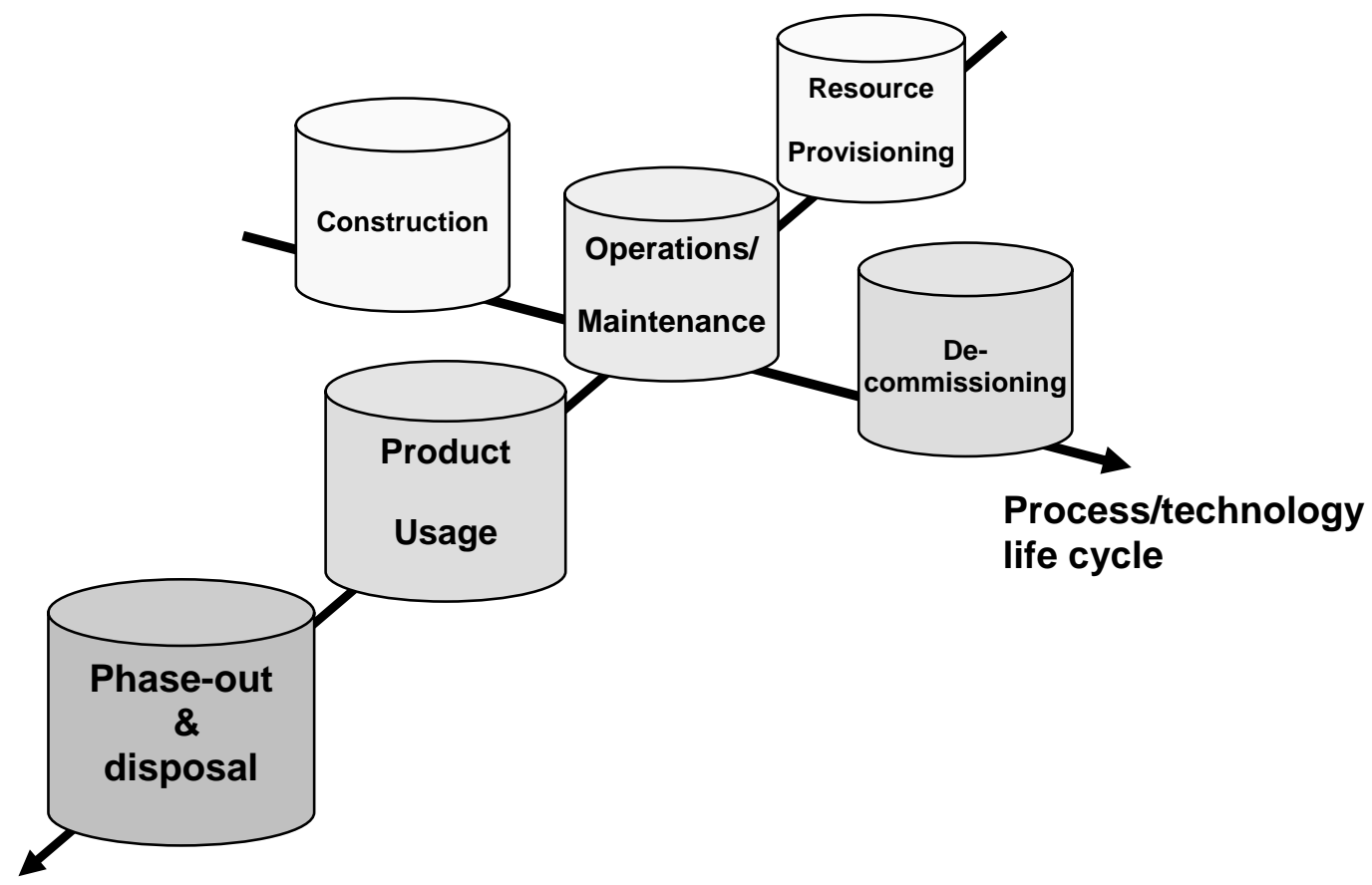

\section{Product life cycle}

Figure 1: The different life cycle phases of an introduced technology in the process industry that must be considered

A SCA evaluation of the sustainability of a technology must therefore clearly establish, in a transparent manner, which life cycle phases are included or excluded 
in the evaluation. Determining the aspects that are considered in an evaluation could have an important influence on the outcomes of a technology assessment study.

The choice of the Secunda site is not ideal for natural gas GTL manufacturing when transport to and from the facility is taken into account. Because of its limited natural gas resources, the South African process industry is forced to obtain its primary feedstock elsewhere. In the case of Secunda, natural gas is obtained by means of a pipeline from Mozambique [1]. This is considered an inevitable limiting condition, and therefore forms part of the context in which the technology is deployed.

Apart from the impacts associated with obtaining the natural gas feedstock, impacts resulting from the electricity requirement of the evaluated GTL facility are also included, since these impacts were expected to be significant. All other supporting industries of the operational activity are excluded from the boundaries, since these are considered to be minor in comparison with the evaluated impacts [2]. Also, the life cycle of the manufactured product is not considered in order to simplify the assessment case study. The case study therefore focuses only on the sustainability of the manufacturing GTL technology, and not on the manufactured product.

Furthermore, the flows of materials that result from the construction, use, and decommissioning of production capital in the process life cycle are not considered in the assessment. This capital consists of the physical structure of the plant, and of supplies and services facilitating operations other than raw materials for the production process. Calculations made in the ExternE project [5] show that the environmental impacts associated with material inputs to fossil power plants are two to three orders of magnitude lower than those at the power generation stage. Similar numbers are assumed for a GTL plant.

\subsection{The functional unit of the case study}

To account for and compare the impacts associated with the inventory results of the case study, it is necessary to select one functional unit to use when reporting the results. The functional unit that is used for the assessment is "a barrel of fuel produced on an annual basis". The choice of a barrel, rather than a metric unit such as a tonne, is that the unit is generally used in the industry sector, and no conversion is needed when adopting data from literature.

\section{ECONOMIC SUSTAINABILITY OF THE GTL TECHNOLOGY}

The economic sustainability of a GTL operation is based on the financial figures of the specific technology. The indicators that are taken into account with the SCA procedure are the operational activity's profit after tax, and the additional financial benefits (see part 1).

The profitability of the GTL technology is based on financial data of the current coal-conversion operation in Secunda [1]. Therefore, the estimated marginal production profitability of the GTL conversion from natural gas is assumed to be at least comparable to the current operations with coal as feedstock - i.e. a company in 
a developing country would not consider converting to a new feedstock if it was not the more economically feasible option.

The assessment only focuses on the fuels produced (and not on other chemical products) and therefore it is necessary to determine which part of the profit made by the Secunda operations can be attributed to the fuel production. To do so, the annual turnover in terms of fuel sales and the profit margin on these fuels is established, based on the regulated wholesale fuel price in South Africa [6]. The profit after tax (or attributable earnings) of the GTL fuel that is currently produced at Secunda is $115.50 \mathrm{R} / \mathrm{bbl}$ based on 2002 prices [7]. The profitability of manufacturing GTL fuel from natural gas would therefore be at least this amount. The profitability of these types of operations includes all additional financial benefits - e.g., subsidies from government - and these are not reported on separately for the case study.

\section{ENVIRONMENTAL SUSTAINABILITY OF THE GTL TECHNOLOGY}

Two steps are required to process the relevant data to assess the environmental impacts associated with the GTL technology. Firstly, an inventory has to be made that catalogues and quantifies all materials and energy used and the environmental releases arising from all stages in the life cycle system. This is the Life Cycle Inventory (LCI) as defined by the ISO standard 14041 [8]. The second step is to analyse how these uses and releases affect actual and potential environmental and human health areas of concern. This is referred to as the Life Cycle Impact Assessment (LCIA) according to the ISO standard 14042 [8]. The LCIA step is incorporated into the environmental indicators of the SCA procedure.

Three aspects need to be considered when evaluating the environmental sustainability of the GTL technology [7]:

- Distances: for the Secunda setting the pipeline connecting the plant with the gas fields of Temane in Mozambique is $865 \mathrm{~km}$ in length.

- Size of the manufacturing facility: the capacity of the hypothetical plant is assumed to be equal to the current coal-based facility (118 $000 \mathrm{bpd}$ ), and is similar to the capacities of the plants discussed in literature with respect to LCIs [2].

- Influence of population density: the health impacts associated with regional pollution directly relate to the population density in the close and remote vicinity of the manufacturing plant. For the case study, cost data from other studies [9] and site-specific dispersion patterns of regional air pollutants [3] are used to determine the distance from the plant in which the population is affected by the normal operation of the plant. In this way, the areas around Secunda that are significantly affected by primary and secondary air pollutants are determined. Thereafter, actual damage costs (or SCA indicators) can be calculated, based on the representative affected population densities. Based on numerical integration, it is estimated that $27 \%$ of the total primary pollutants are detected within a 30-kilometre radius of the source, within which all of the major towns around Secunda, with a population density of 242 inhabitants $/ \mathrm{km}^{2}$, are located [7]. The remaining $73 \%$ affects an average population density equal 
to that of the area in a 500-kilometre radius from the plant (54 inhabitants $/ \mathrm{km}^{2}$ ) [7]. The outer boundary is therefore set at $500 \mathrm{~km}$. These areas are shown in Figure 2.

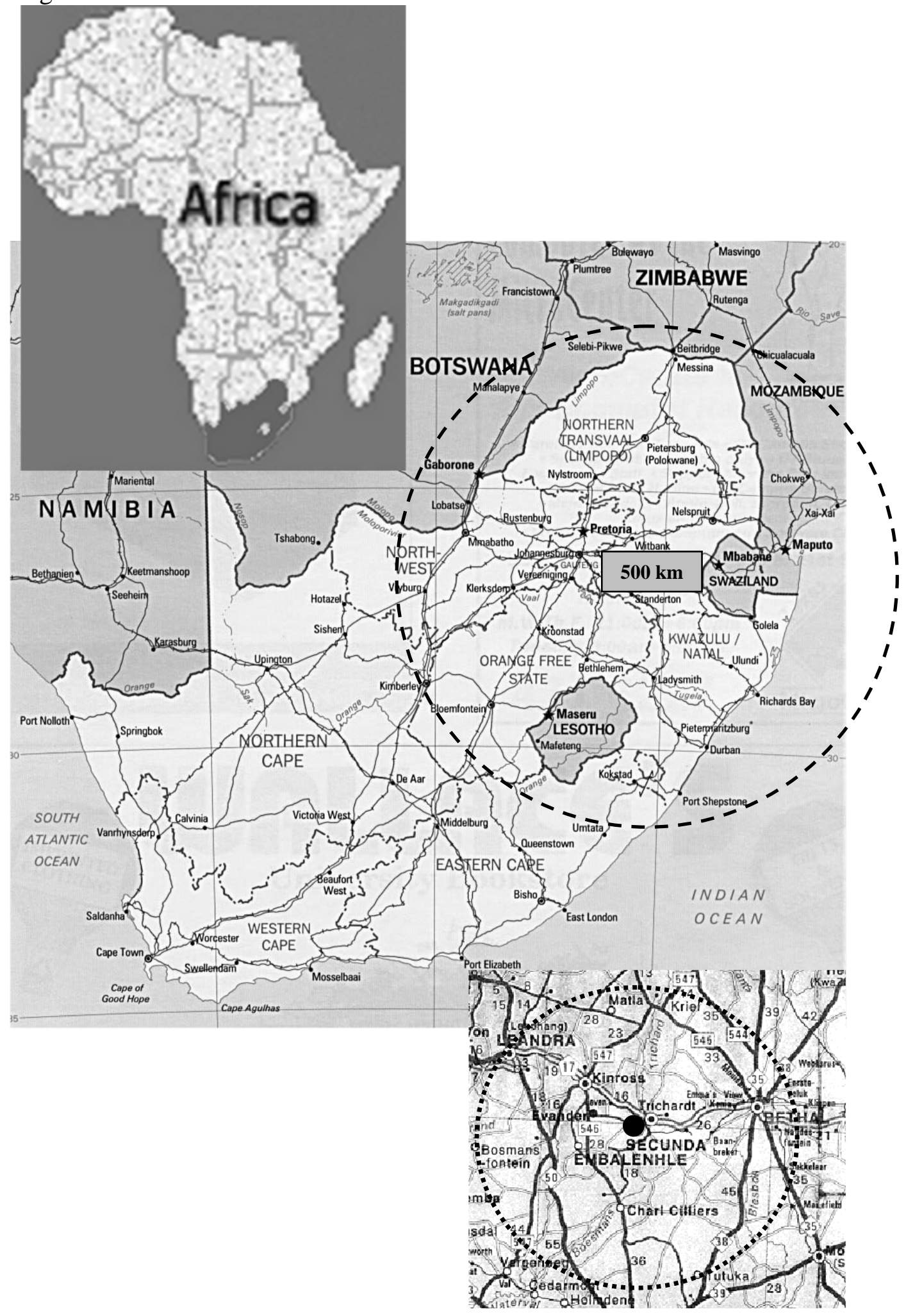

Figure 2: Close $(30 \mathrm{~km})$ and remote $(500 \mathrm{~km})$ areas affected by regional pollutants of the Secunda manufacturing facility 


\subsection{Impacts on air resources}

The Life Cycle Inventory (LCI) of the air emissions [2] of the full life cycle is shown in Table 1 [7]. With respect to the impacts on a global level, the only damage costs caused by emissions of $\mathrm{N}_{2} \mathrm{O}$ and $\mathrm{CH}_{4}$ are attributable to the contributions to greenhouse effects, and these pollutants are not reported separately. Rather, the $\mathrm{CO}_{2}$ equivalent totals are added [10]. By multiplying the adjusted damage costs (or indicators) of the SCA procedure by the amount of air pollutants emitted, the total damage cost is calculated (see Table 1) [7].

\begin{tabular}{|c|c|c|c|c|}
\hline & & $\begin{array}{c}\text { Emissions } \\
\text { (g/bbl) }\end{array}$ & $\begin{array}{c}\text { Damage } \\
\text { (R/kg) }\end{array}$ & $\begin{array}{c}\text { Total damage } \\
\text { cost } \\
\text { (R/bbl) }\end{array}$ \\
\hline Global & $\begin{array}{l}\mathrm{CO}_{2} \\
\text { equivalent }\end{array}$ & 194948 & 0.221 & 43.2 \\
\hline \multirow[t]{7}{*}{$\begin{array}{l}\text { Regional } \\
\text { (health) }\end{array}$} & $\begin{array}{l}\mathrm{SO}_{\mathrm{x}} \\
\text { (primary) }\end{array}$ & $13.9^{\mathrm{a}}$ & 1.63 & 0.02 \\
\hline & $\begin{array}{l}\mathrm{SO}_{\mathrm{x}} \\
\text { (secondary) }\end{array}$ & $13.9^{\mathrm{a}}$ & 27.8 & 0.39 \\
\hline & $\begin{array}{l}\mathrm{NO}_{\mathrm{x}} \\
\text { (secondary) }\end{array}$ & 703 & 43.9 & 30.8 \\
\hline & $\mathrm{NO}_{\mathrm{x}}\left(\right.$ via $\left.\mathrm{O}_{3}\right)$ & 703 & 3.21 & 2.3 \\
\hline & $\mathrm{CO}$ & 118 & 0.109 & 0.013 \\
\hline & VOC & 876 & 2.1 & 1.80 \\
\hline & $\mathrm{PM}$ & 15.1 & 84 & 1.26 \\
\hline $\begin{array}{l}\text { Regional } \\
\text { (buildings) }\end{array}$ & $\mathrm{SO}_{2}$ & 13.9 & 1.37 & 0.02 \\
\hline \multirow{2}{*}{$\begin{array}{l}\text { Regional } \\
\text { (crops) }\end{array}$} & $\mathrm{NO}_{2}$ & 13.9 & 1.60 & 1.12 \\
\hline & VOC & 703 & 0.89 & 0.62 \\
\hline Total & & & & 81.6 \\
\hline
\end{tabular}

a Amounts of $\mathrm{SO}_{\mathrm{x}}$ are assumed to be the same for both primary and secondary impacts. The emitted primary pollutants are partially converted into secondary pollutants. The damage costs for both pollutants are calculated based on an average conversion velocity, whereby a certain amount maintains its original form and deposits as primary pollutant, and the rest reacts into secondary pollutants. The damage costs of these secondary pollutants are expressed per amount of emitted primary pollutant.

Table 1: Damage costs of considered air pollution impacts per barrel of GTL produced

\subsection{Impacts of water use}

Water is mainly used for cooling processes during GTL fuel manufacturing, and because of the relatively high temperatures in South Africa, it can be expected that water consumption is high. It has been assumed [7] that the water consumption of a GTL plant in the South African setting is $30 \%$ higher than the quantities proposed in 
literature [2]. The water consumption of the GTL plant for this case study is therefore 2256 litres per barrel of fuel manufactured.

Studies indicate that there is a scarcity of water in the region of Secunda, and that the amount of water that is extracted from the catchment already exceeds the natural supply of the water reserve $[3,11]$. Therefore, the damage costs as a result of water use do apply; the opportunity costs, as indicated in the SCA procedure (benefit approach) are used to assess the damage cost for the total water consumption [7].

The total opportunity costs of the water consumed are estimated to be $5.44 \mathrm{R} / \mathrm{bbl}$. After subtracting the current price paid for the consumption of this water, the externality costs resulting from water use are $4.49 \mathrm{R} / \mathrm{bbl}$.

\subsection{Impacts of land use}

The land use of the case study results from the constructed pipeline and the manufacturing plant itself. The impact at the gas extraction site is minor, since the surface is scarcely affected.

The 865-kilometre subsoil pipeline from Mozambique to the plant in Secunda will be overgrown with natural cover after construction. The impacts associated with land use are therefore considered minimal. The area of the current plant itself, 2100 hectares [1], is considerable. For the case study it is assumed that this land area would be similar for a GTL process with natural gas as a feedstock.

The land types affected as a result of the GTL conversion are predominantly grassand rangeland (66\%) and cropland (34\%) [3]. The assumption is made that the division of the land use reported in the SEA reflects the division of land use for the Secunda GTL operation. Multiplying these percentages of the total affected area by the damage costs and converting to 2002 South African prices, the damage costs as a result of land use amount to $0.08 \mathrm{R} / \mathrm{bbl}$ of GTL fuel produced [7].

\subsection{Impacts of the use of mined abiotic resources}

The damage costs for the case study reflect the depletion of the gas fields in Mozambique. The current estimates state that the combined Temane and Pande gas reserves in Mozambique have a capacity of 3.2 trillion cubic feet [1]. With a production capacity of $118000 \mathrm{bbl}$, the Secunda plant would need 1.21 billion cubic feet of natural gas per day. At this rate of depletion, the life span of the reserves would be 8.3 years.

The discount rate is assumed to be $4 \%$ (see Part 1 ), and the user costs of the SCA procedure are $69 \%$ of the profit made from selling the natural gas [7]. Based on the current natural gas sales to many industrial customers in South Africa, the total user costs amount to $56.00 \mathrm{R} / \mathrm{bbl}$. 


\section{SOCIAL SUSTAINABILITY OF THE GTL TECHNOLOGY}

For the GTL case study, the social indicators of the SCA procedure mainly use the current operations in Secunda as a benchmark [1]. Expenditures that contribute to social sustainability are often reported for the whole company. Examples are expenditure on taxes, wages, training and education, and research and development.

\subsection{Impacts on internal human resources}

The total expenditure on wages, including contributions to the Unemployment Insurance Fund (UIF), life insurance, and medical aid, was 1,205.2 million Rand after tax for the 5872 employees of the Secunda operations in 2002. Only 66\% of the sales of the products were obtained from fuels, and therefore it is assumed that 795.4 million Rand was spent on workforce compensation to produce fuels. The workforce that is not accounted for in the life cycle system is employed in the upstream processes (or supply chain). It is assumed that this number will be small by comparison, since the extraction of natural gas is not a labour-intensive process.

For the production of fuel at the Secunda operations, 49.4 million Rand was assigned for the training and education of employees in 2002, including student bursaries for tertiary education. It is assumed that training includes the aspects of health and safety. Specific losses for the company due to the incapacity of employees resulting from health and safety incidents have been excluded from the case study.

The expenditure on research and development on behalf of the Secunda operations was estimated to be 202 million Rand, of which 66\% is attributable to the production of fuels, i.e. 133 million Rand.

Based on a production capacity of $118000 \mathrm{bbl} /$ day, the total expenditure on employment stability is $18.50 \mathrm{R} / \mathrm{bbl}$, and on capacity development $3.90 \mathrm{R} / \mathrm{bbl}$. Consequently, the total expenditure on internal human resources for the GTL technology is estimated to be $22.40 \mathrm{R} / \mathrm{bbl}$ of fuel produced.

\subsection{Impacts on the external population}

The sub-criteria of external population include impacts on "human capital" and “community capital” (see Part 1).

Contributions to human capital are only directly attributable to an operational activity where a government stipulates that an operational initiative may only continue if it contributes financially to local medical or educational facilities. In Mozambique, 5.5 million Rand is invested in the renovation of public schools during the construction of the natural gas pipeline [12], which amounts to $0.13 \mathrm{R} / \mathrm{bbl}$ of fuel produced. The investment in the schools represents the first planned social development project, as an additional financial burden to the natural gas project.

With respect to community capital, an amount similar to the investment in schools is spent on productive capital, e.g. the supply of water, and on other community capital, 
e.g. recreation facilities, in Mozambique. The precise impacts of the fuel manufacturing operations on community capital are difficult to determine. An attempt is made, however, to quantify the impacts of the Secunda operation on real estate value in the affected area. The local municipality and real estate agents determine these real estate values.

Section 2.1 indicated that the only major industrial activity in the close vicinity of Secunda - other than the coal mines that supply the manufacturing process with coal - is the CTL process itself. The hypothetical case study assumes that industrial activity would remain similar if natural gas was used as feedstock. It is obvious that the development of the plant provided an incentive for other economic activities to emerge in the area to address the population needs. However, apart from this industrial activity, the setting does not have significant economic advantages or disadvantages over neighbouring areas. The possible differences in secondary or supporting economic activities can be related to the difference in welfare level resulting from the main economic activity, i.e. the Secunda operations. Therefore, a difference is expected between economic activity and house prices in the Secunda area and the average house prices in the neighbouring areas - i.e. it is assumed that no tangible causes other than the operational initiative of the GTL technology influence local house prices. Consequently, our approach attempts to correlate the variations in the house prices with their distance from the plant. The objective is to compare similar settings at varying distances from the plant.

The average real estate price for a 3-bedroom house is the basis on which the analysis is performed. It is assumed that price differences between these residences indicate the price differences of all real estate in the area. Based on an interview with a local real estate agent, it is estimated that real estate values in the towns of Bethal and Leandra (see Figure 3) reflect the standard house prices in the area outside the circle of influence of the Secunda operations. Based on this estimate, the impact on house prices is confined to a radius of 25 kilometres or less. The base price of a standard 3-bedroom property is set at R250 000. Using this base price, the costs of a standard 3-bedroom house in Secunda and in the towns of Trichardt and Kinross are compared, together with the distances from the plant (see Figure 3) [7].

A standard 3-bedroom house in Secunda is more expensive than the base price. This indicates that real estate closer to the plant is more highly appreciated owing to the travelling preference of many employees, regardless of local nuisance levels such as pollution and poor visual aesthetics. Although Trichardt and Kinross are further from the plant, the nuisance levels are lower; and the trade-off between these two influences results in higher real estate prices in these more distant towns.

It must be emphasised that the price curve shown in Figure 3 is crude, and it would be wrong to expect a high degree of accuracy in the valuation of this non-transparent impact to be achieved using this method. However, the figures provide an order of magnitude of the impact of the operational initiative on real estate prices. By using the difference in real estate prices, and the total real estate value in the area affected, the total impact on community capital is estimated. Based on the total values and the impact on these values (in \%), the difference in value attributable to the industrial 
activity is calculated (see Table 2). The total positive impact on real estate value is estimated at 552 million Rand.

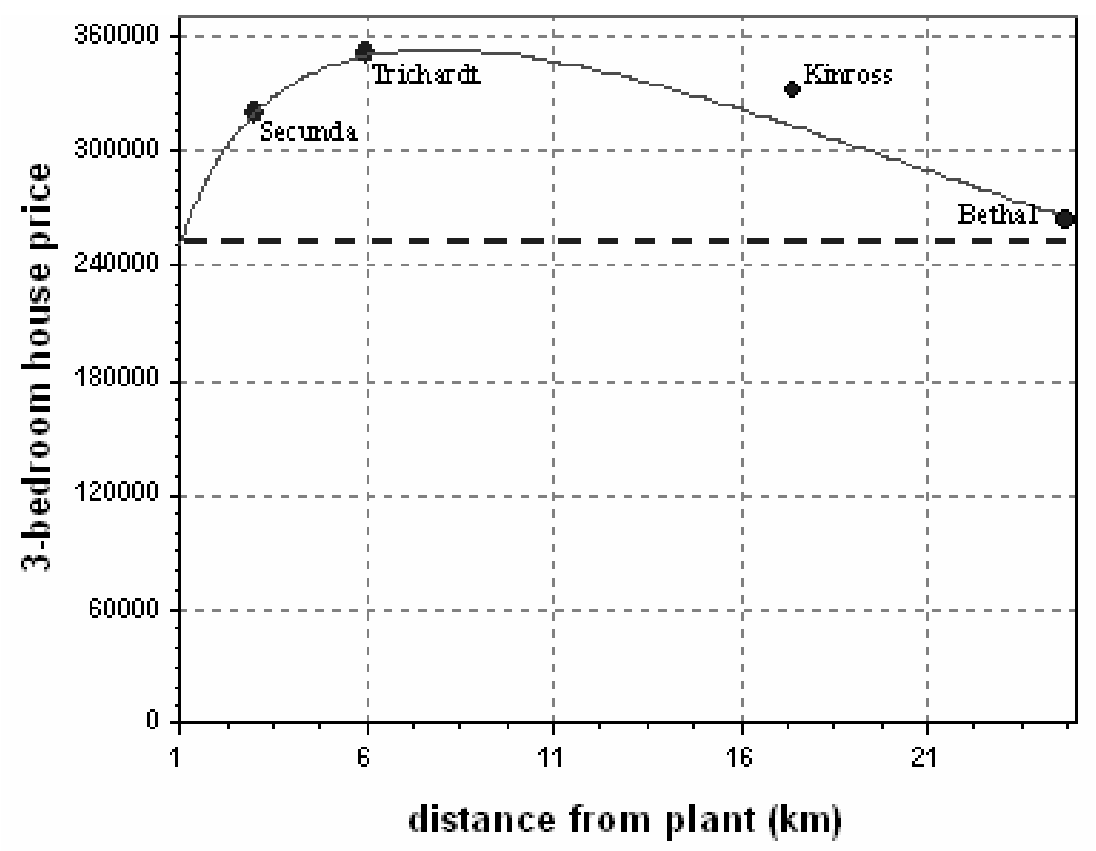

Figure 3: House prices in the vicinity of the Secunda plant (in Rands)

\begin{tabular}{|l|c|c|c|c|c|}
\hline & $\begin{array}{c}\text { Number of } \\
\text { real estate } \\
\text { units }\end{array}$ & Total value & $\begin{array}{c}\text { Ratio of } \\
\text { house price } \\
\text { to base } \\
\text { price }\end{array}$ & $\begin{array}{c}\text { Normalised } \\
\text { total value }\end{array}$ & $\begin{array}{c}\text { Difference in } \\
\text { value }\end{array}$ \\
\hline Secunda & 8128 & 855570721 & 1,28 & 668414626 & 187156095 \\
\hline Embalenhe & 31480 & 633172912 & 1,40 & 452266366 & 180906546 \\
\hline Evander & 2299 & 359396000 & 1,36 & 264261765 & 95134235 \\
\hline Kinross & 3420 & 175399300 & 1,20 & 146166083 & 29233217 \\
\hline Trichardt & 920 & 209775800 & 1,40 & 149839857 & 59935943 \\
\hline
\end{tabular}

\begin{tabular}{l|r|} 
Total & 552366036
\end{tabular}

Table 2: Real estate values in the case study area affected by the Secunda operations (in Rands)

The method used to convert this impact to a barrel of fuel is based on the potential earnings made on the increase in real estate value. The mortgage rate in South Africa in 2002 was $15 \%$. The discount rate for these investments is assumed to be $6 \%$. The annual net earnings from mortgages on the total extra added value, therefore, would be $9 \%$ of 552 million Rand. This is about 50 million Rand per year, or $1.15 \mathrm{R} / \mathrm{bbl}$ of fuel produced. 


\subsection{Stakeholder participation}

The total expenditures of the Secunda operations on stakeholder participation (as defined by the SCA procedure indicators) are estimated to be 50 million Rand annually [1]. This is equivalent to $0.77 \mathrm{R} / \mathrm{bbl}$ (Van Erck 2003).

\subsection{Macro-social performance}

The impacts categorized under macro-social performance are subdivided into socioenvironmental and socio-economic performances (see Part 1).

With respect to socio-environmental performance, seven stations are operated in the vicinity of the Secunda plant to monitor the ambient air quality. In addition five stations monitor the water quality in the surface waters surrounding the plant. The company is also involved in a joint undertaking with the national government to improve monitoring in areas throughout the country that are either ecologically sensitive or exposed to significant amounts of pollutants [1, 3]. It is estimated that the annual expenditure on these monitoring activities amounts to 2 million Rand. This is equivalent to about $0.05 \mathrm{R} / \mathrm{bbl}$ of fuel produced [7].

The socio-economic performance of the operational initiative is measured by its tax contribution to the government. Three types of tax are transferred from a South African company to the government:

- Tax on profits: the amount attributable to the production of fuels based on the total sales of fuels and the average tax percentage that was paid in 2002. The total tax on profit that the Secunda operation paid was 2,619.8 million Rand; and according to the distribution of sales, 1,729 million Rand is attributable to the sales of fuels. This is equivalent to $40.10 \mathrm{R} / \mathrm{bbl}$.

- Tax on wages: the amount attributable to the production of fuels is based on the number of employees working at the Secunda facility. Based on the ratio of sales between fuels and other products from Secunda, the amount of tax on wages attributable to the production of fuels in 2002 was 261.5 million Rand. This is equivalent to $4.40 \mathrm{R} / \mathrm{bbl}$.

- $\quad$ Other taxes, e.g. property taxes: attributed in a similar way to the tax on profits, which amounts to $0.90 \mathrm{R} / \mathrm{bbl}$.

The total contribution to socio-economic performance is therefore $45.50 \mathrm{R} / \mathrm{bbl}$. 


\section{OVERALL SUSTAINABILITY PERFORMANCE OF THE GTL TECHNOLOGY}

\begin{tabular}{|c|c|c|c|}
\hline (Sub)criteria & $\begin{array}{r}\text { Score } \\
\left(\mathbf{R}_{2002} / \mathbf{b b l}\right)\end{array}$ & Significance $^{a}$ & Comments \\
\hline Economic dimension & 115.10 & & \\
\hline Financial health & 115.10 & High & $\begin{array}{l}\text { The following have not been } \\
\text { taken into account: } \\
\text { contributions to corporate } \\
\text { head office, auxiliaries, and } \\
\text { research and development } \\
\text { activities that occur off-site }\end{array}$ \\
\hline $\begin{array}{l}\text { Environmental } \\
\text { dimension }\end{array}$ & -142.17 & & \\
\hline $\begin{array}{l}\text { Air resources } \\
\text { Regional impacts } \\
\text { Global impacts }\end{array}$ & $\begin{array}{l}-81.60 \\
-38.30 \\
-43.30\end{array}$ & High & $\begin{array}{l}\text { Low estimate of the ExternE } \\
\text { accounting framework [5] }\end{array}$ \\
\hline $\begin{array}{c}\text { Water resources } \\
\text { Water use }\end{array}$ & $\begin{array}{l}-4.49 \\
-4.49\end{array}$ & Low & $\begin{array}{l}\text { Based on published } \\
\text { estimates [13] }\end{array}$ \\
\hline $\begin{array}{l}\text { Land resources } \\
\text { Land use }\end{array}$ & $\begin{array}{l}-0.08 \\
-0.08\end{array}$ & Low & $\begin{array}{l}\text { Only land use of the plant } \\
\text { taken into account }\end{array}$ \\
\hline Mined abiotic resources & -56.00 & High & $\begin{array}{l}4 \% \text { discount rate, based on } \\
\text { local proven reserves }\end{array}$ \\
\hline Social dimension & 70.05 & & \\
\hline $\begin{array}{l}\text { Internal human resources } \\
\text { Employment stability } \\
\text { Capacity } \\
\text { development }\end{array}$ & $\begin{array}{r}22.35 \\
18.50 \\
3.85\end{array}$ & High & \\
\hline $\begin{array}{l}\text { External population } \\
\text { Human capital } \\
\text { Community capital }\end{array}$ & $\begin{array}{l}1.41 \\
0.13 \\
1.28\end{array}$ & Low & \\
\hline Stakeholder participation & 0.77 & Low & \\
\hline $\begin{array}{l}\text { Macro social } \\
\text { performance } \\
\text { Socio-environmental } \\
\text { Social-economic }\end{array}$ & $\begin{array}{r}45.55 \\
0.05 \\
45.50\end{array}$ & High & $\begin{array}{l}\text { See the comments on } \\
\text { 'financial health' }\end{array}$ \\
\hline
\end{tabular}

A score value for a criterion that contributes less than $5 \%$ to the overall score of a sustainable development dimension is not considered significant.

\section{Table 3: SCA results of the GTL conversion technology assessment}

\subsection{Results of the SCA assessment}

The overall results of the SCA procedure, as applied in assessing the sustainability performance of the GTL conversion technology in the Secunda setting, are summarised in Table 3. The internal financial health of the technology is the only 
criterion that is evaluated in terms of the economic dimension of sustainable development. The results indicate an overall positive contribution by the technology to this dimension. In contrast, the technology has seriously negative impacts on the external natural environment beyond the geographical boundaries of the technology. The largest impacts of the life cycle system are attributable to atmospheric emissions and the use of non-renewable resources, i.e. natural gas as a feedstock to the GTL process, and coal for the generation of the required electricity. Water use is of lower significance, although important in the South African context. In total, the negative impacts on the environmental dimension outweigh the positive contribution of the technology to the (internal) economic dimension. However, the technology does have a positive effect on the social dimension, with the largest contributions being made by the wages (for direct employees) and socio-economic benefits (through taxes paid by the company to society). The impacts on the other social sub-criteria are minimal.

The assessment considers the deployment of a technology in a specific setting. Sitespecific variables strongly determine the outcome. Therefore, when drawing conclusions based on this data, prudence is called for - especially in linking results to the application of the technology in general.

\section{DISCUSSION OF THE SCA PROCEDURE}

\subsection{The sustainability performance assessment framework}

We recognise that there are significant limitations in the choice of the methodology for the sustainability performance assessment. Owing to the application of a monetary appraisal procedure, some of the criteria in the comprehensive sustainability performance assessment framework are ignored in the analyses [7].

Difficulties occur especially with the limited capacity that the monetary appraisal approach has to recognise, and therefore distinguish between qualitative differences in impacts. An example is the problem of appraising the criterion "financial health" in terms of solvency and liquidity, instead of merely by the company's profitability. Furthermore, the monetary appraisal method is inadequate to the task of correcting for inefficient market mechanisms. An efficient market mechanism regulates the value of scarce and ample assets by price levels. If price levels do not reflect the true value of an asset - for example, if there are not sufficient feasible alternatives to choose from - or if price levels do not exist for certain assets, the SCA procedure will not correct for these shortcomings. For example, expenditures on research and development activities are appraised as equal to expenditures on wages, whereas equal benefits are not necessarily realised within a company.

\subsection{The uncertainty of data that is used in the case study}

The uncertainty of the SCA results may be more problematic than the usefulness of the outcome of an assessment. A prerequisite for incorporating the outcome of a SCA assessment in decision-making is that the results should be sufficiently accurate. If there is significant uncertainty about the results of the sustainability 
criteria that are measured, integrating the SCA outcome with other decision-making aspects will become increasingly difficult. As long as there is a clear understanding about what is excluded in the assessment, the results may be useful. Therefore, the uncertainty of results is a more significant weakness in the procedure than its limited ability to recognise qualitative differences or to account for all relevant sub-criteria of the sustainability performance assessment framework.

The inaccuracy of data adopted from literature, the conversion methods applied, and specifications in the Secunda setting - these all cause a margin of error in the end results of the SCA procedure. Based on these uncertainties, an attempt has been made to quantify this margin of error [7]. Apart from the appraisal of "community capital", an assessment of the margin of error for the economic and social indicators was not considered necessary - that is, the data obtained from company publications were believed to be accurate. Also, the "community capital" criterion has a small influence on the overall sustainability performance evaluation, and the uncertainty of the data is not regarded as significant to the outcome of the case study (see Table 3).

The discount rate that is applied to calculate long-term environmental impacts is chosen arbitrarily. The consequence of manipulating the discount rate for long-term environmental damage costs has been illustrated [14]. A lower discount rate implies higher current damage costs, because the present values of future losses are weighted more highly. For example, whereas a damage of $\$ 100$ in 100 years would amount to $\$ 5$ (using a discount rate of $3 \%$ ) in present day terms, the damage would amount to $\$ 37$ if a 1\% discount rate were used. In other words, by applying higher discount rates, a lower present value of future damages will result. Although the SCA results do depend on the chosen discount rate, it must be emphasised that the overall outcomes and conclusions would not be significantly influenced for this case study.

\section{CONCLUSIONS AND RECOMMENDATIONS}

The Sustainability Cost Accounting (SCA) procedure we introduced in Part 1 of this paper has been demonstrated and assessed in the context of the South African petrochemical industry, specifically the Gas-to-Liquid (GTL) conversion of natural gas into liquid fuel at the location of Secunda in central South Africa.

The SCA procedure shows certain limitations. Firstly, the concept of sustainability cannot be comprehensively expressed in monetary terms. Consequently, not all of the criteria that are considered relevant in assessing sustainability performances can be measured. Secondly, although the SCA procedure is generally applicable, the values used by the different indicators have to be evaluated on a case-by-case basis and reported in a transparent manner. Also, the uncertainty of the data that is obtained, and on which the SCA assessment is based, may strongly influence the usability of a sustainability performance assessment's results - for example, future damage costs will change with the fluctuations of the markets. However, this does not mean that the SCA procedure is incapable of improving the understanding of a technology's sustainable performance. The criteria that are measured are all considered relevant to the assessment of a technology's sustainability. 
Apart from the implications that the limitations of the approach raise, it is a challenge to interpret the scores of the different dimensions of sustainable development. Assessing a technology's sustainability performance by allowing trade-offs between the contributions and damages should be seriously considered before it is applied. Ultimately, the trade-offs between the different dimensions would be the responsibility of the specific decision-makers, and would therefore reflect the preferences of the decision-makers.

This does not imply that the results are unsuited to helping a company to improve the sustainability performance of a deployed technology. The results of each sustainability dimension can function as a benchmark for subsequent sustainable performances, or for identifying improvement possibilities for a developed technology. It is, however, unjustifiable to label different activities as more or less sustainable, based merely on such results.

\subsection{Recommendations}

In general, we can observe that the results of the SCA procedure are open to dispute, and this limits the possibility of using them in decision-making or technology management. The approach does show potential, however, and some aspects need further attention to improve the usefulness of such a SCA procedure. Therefore, two recommendations are made to establish the usefulness of this approach and possibly to extend parts of it:

- In most cases, the monetary route uses only one or two indicators to measure the sub-criteria, where some are considered impossible to appraise. We therefore propose that the monetary assessment methodology be combined with qualitative indicators for an overall sustainability performance assessment. Such an approach should be tested with further case studies.

- As discussed, the uncertainty of data is considered the main problem in using the outcome of the SCA in decision-making. Damage cost estimates must therefore be refined, especially if the procedure is applied in developing countries such as South Africa.

\section{REFERENCES}

[1] Sasol. 2002. Share it with Sasol, Sasol Sustainability report 2000-2002, Johannesburg.

[2] Marano, J.J. and Ciferno, J.P. 2001. Life-Cycle Greenhouse-Gas Emissions Inventory For Fischer-Tropsch Fuels, Energy and Environmental Solutions, LLC, prepared for U.S. Department of Energy National Energy Technology Laboratory.

[3] Council for Scientific and Industrial Research (CSIR). 2000. A Strategic Environmental Assessment for Sasol, Secunda, Division of Water, Environment and Forestry Technology (Environmentek), Pretoria.

[4] Labuschagne, C. and Brent, A.C. 2005. Sustainable Project Life Cycle Management: The need to integrate life cycles in the manufacturing sector, International Journal of Project Management, 23(2), pp 159-168. 
[5] European Commission. 1997. Maintenance, Improvement, Extension and Application of the ExternE Accounting Framework, Directorate-General XII, Brussels.

[6] Department of Minerals and Energy (DME). 2003. Data retrieved from http://www.dme.gov.za on 26 July 2003.

[7] Van Erck, R.P.G. 2003. Monetary evaluation of business sustainability. Case study: GTL fuel production in South Africa, Masters thesis, Department of Technology Management, Technical University Eindhoven \& Department of Engineering and Technology Management, University of Pretoria.

[8] International Organisation for Standardisation (ISO). 2006. http://www.iso.org/, accessed on 4 January 2006.

[9] Spadaro, J.V. and Rabl, A. 2002. Air pollution damage estimates: The cost per kilogram of pollutant, International Journal of Risk Assessment and Management, 3(1), pp 75-97.

[10] Guinée, J.B., Gorrée, M., Heijungs, R., Huppes, G., Kleijn, R., de Koning, A., van Oers, L., Sleeswijk, A.W., Suh, S., de Haes, H.A.U., de Bruijn, H., van Duin, R. and Huijbregts, M.A.J. 2001. Life cycle assessment - an operational guide to the ISO standards, Centre for Environmental Studies (CML), Leiden University.

[11] Basson, M.S., van Niekerk, P.H. and van Rooyen, J.A. 1997. Overview of water resources availability and utilisation in South Africa, Department of Water Affairs and Forestry report P RSA/00/0197, Pretoria.

[12] Sasol. 2003. Data retrieved from http://www.sasol.com on 26 February 2003.

[13] Van Horen, C. 1996. The Cost of Power: Externalities in South Africa's Energy Sector, Doctoral thesis, University of Cape Town.

[14] Degenhardt, S. 1998. The Social Costs of Climate Change, A Critical Examination, Contribution to the workshop: "Carbon Sequestration in Forests Research Agenda after Kyoto”, Finland. 